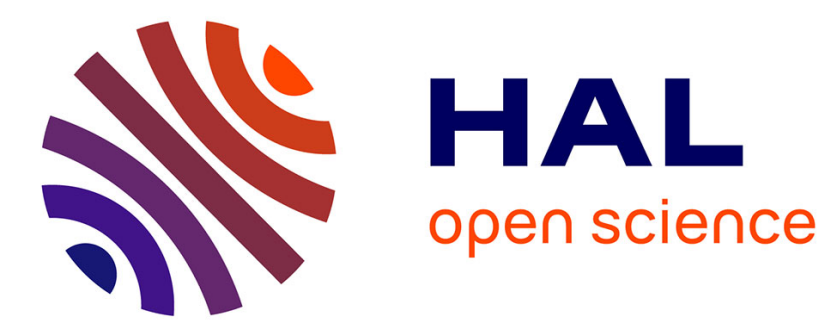

\title{
Solitary wave in a slender rod of constant curvature
}

S. Rybak, Yu. Skrynnikov

\section{To cite this version:}

S. Rybak, Yu. Skrynnikov. Solitary wave in a slender rod of constant curvature. Journal de Physique IV Proceedings, 1994, 04 (C5), pp.C5-805-C5-807. 10.1051/jp4:19945173 . jpa-00252854

\section{HAL Id: jpa-00252854 https://hal.science/jpa-00252854}

Submitted on 1 Jan 1994

HAL is a multi-disciplinary open access archive for the deposit and dissemination of scientific research documents, whether they are published or not. The documents may come from teaching and research institutions in France or abroad, or from public or private research centers.
L'archive ouverte pluridisciplinaire HAL, est destinée au dépôt et à la diffusion de documents scientifiques de niveau recherche, publiés ou non, émanant des établissements d'enseignement et de recherche français ou étrangers, des laboratoires publics ou privés. 


\title{
Solitary wave in a slender rod of constant curvature
}

\section{S.A. RYBAK and Yu.I. SKRYNNIKOV}

N.N. Andreev Acoustics Institute of Russian Academy of Sciences, 4 Shvernik Street, 117036 Moscow, Russia

\begin{abstract}
ABSTRACr: An equation is derived to describe the propagation of nonlinear strain wares in a rod of constant curvature. A solution is obtained in the form of a steady-state solltary wave with symetrical leading and trailing edges.
\end{abstract}

A number of papers have been devoted to aspects of the propagation of elastic waves in straight rods [1,2]. Samsonor [2] has dertred a nonlinear equation for a longitudinal strain wave in a slender rod. The steady-state solution of his equation are the regult of balance between a second-order nonlinearlty of the hydrodynamic type and dispersion of the form

$$
\omega^{2}=c_{0}^{2} k^{2}-\frac{\nu^{2} a^{2}}{2}\left(\omega^{2}-c_{1}^{2} k^{2}\right) k^{2},
$$

where $c_{0}$ and $c_{1}$ are the velocities of linear longitudinal and shear wares, $\nu=\lambda(\lambda+2 \mu)^{-1}$, and $a$ is the radius of the rod's crosssection.

If the rod is not straight, but curres into an arc of radius $R$, another term must be added to the dispersion relation (1) [3]:

$$
\omega^{2}=c_{0}^{2} k^{2}-\frac{\nu^{2} a^{2}}{2}\left(\omega^{2}-c_{1}^{2} k^{2}\right) k^{2}+c_{0}^{2} R^{-2} \text {. }
$$

The addition to Eq.(1) because of the curvature of the rod can be declsive in some cases (e.g., when ak * 1 or $\mathrm{kR} * 1$ ). Consequentis, it makes sense to reatrict the problem to klein-Gordon dispersion in the 
long-wavelength approrimation:

$$
p^{2}=c_{0}^{2} x^{2}+c_{0}^{2} \mathrm{R}^{-2} \text {. }
$$

Determining the 1inear part from the dispersion relation (2) and adding a second-order nonlinear term [2] to it, we obtain the nonl1near Klein-Gordon equation

$$
u_{t t}-c_{0}^{2} u_{x x}+\left(c_{0} / R\right)^{2} u=\beta\left(u^{2}\right)_{z x},
$$

which describes the propagation of finite-amplitude waves in a curred rod. Here $\beta$ is the nonlinearity parameter of the rod material and $u$ is the $x$-derivative (the $x$ axis is directed along the rod) of the long1tudinal component of the displacement vector, 1.e., the longitudinal stroin.

Our objective is to find steady-state solutions in the form of golltary waves, 1.e., solutions of the form $u=u(\eta)(\eta=x-\nabla t$, where $\nabla=$ const is the wave velocity) that are finite for all values of $\eta$ and ranish together with the derivative $\nabla$ in the limits $\eta \rightarrow \pm \infty$. Integrating once, we really obtain the lollowing expression in the class of steady-state solutions:

$$
\left[\frac{d v}{d \xi}\right]^{2}=4 \frac{\left(\nabla^{2}-\nabla^{3}\right)}{(3 \nabla-2)^{2}}, \quad 0<\nabla<1 .
$$

Here we have introduced the new varlables $\nabla$ and $\xi$ :

$$
\mathrm{u}=-\frac{3}{2}\left[1-\frac{\nabla^{2}}{c_{0}^{2}}\right] \frac{\mathrm{c}_{0}^{2}}{\beta} \mathrm{v} ; \quad \xi=\eta \mathrm{R}^{-1}\left[1-\frac{\nabla^{2}}{\mathrm{c}_{0}^{2}}\right]^{-1 / 2}
$$

Integrating Eq. (4), we obtain the solution

$$
|\xi|=\left\{\begin{array}{c}
3(1-v)^{1 / 2}+\operatorname{In} \frac{1-(1-\nabla)^{1 / 2}}{1+(1-\nabla)^{1 / 2}} ;|\xi|<\xi_{0} ; 2 / 3<\nabla<1 \\
2 \xi_{0}-3(1-\nabla)^{1 / 2}-\operatorname{In} \frac{1-(1-\nabla)^{1 / 2}}{1+(1-\nabla)^{1 / 2}} ;|\xi|>\xi_{0} ; 0<\nabla<2 / 3
\end{array}\right.
$$


where $\xi_{0}=3^{1 / 2}-\operatorname{In}\left(2+3^{1 / 2}\right) * 0.42$. The derivative of function $\nabla(\xi)$ is infinitive at the points $\xi= \pm \xi_{0}$ - Consequently, the ware obtained has two symmetrically located vertical edges. In the vicinity of the edges $\nabla(\xi)$ has a singulartity of the form

$$
\nabla=\frac{2}{3}\left[1-3^{1 / 4} \operatorname{sgn}\left(|\xi|-\xi_{0}\right)\left(2|| \xi\left|-\xi_{0}\right|\right)^{1 / 2}\right) \text {, }
$$

and it is clear just from the procedure used to solve Eq. (3) that this singularity is a consequence of a presence higher derivative of the equation in the nonlinear term.

The tall of the wave, 1.e., the parts that decay infinitely in either direction, have the same structure as the tails of a Kortewegde Vrieg solition. As in the case of the Korteweg-de Vries soliton, the smplitude $A$ and the width $\Delta$ of the wave (5) depend on 1 ts velocity. however, a different relation existg between the amplitude and the width: $\Delta \sim \mathbb{A}^{1 / 2}$.

\section{REAFRERTCES}

[1] Ostrovsk11 L.A. and Sutin A.S., Prikl. Mat. Mekh. 41 (1977) 531.

[2] Samsonov A.K., Sov. Phys. Dok1. 33 (1988) 298.

[3] Isakovich H.A. and Komarova L.N., Sor. Phys. Acoust. 13 (1968) 491. 